\title{
Detection of specific antibodies to pigeon serum and bloom antigens by enzyme linked immunosorbent assay in pigeon breeder's disease
}

\author{
M J Rodrigo, M I Benavent, M J Cruz, M Rosell, C Murio, C Pascual, F Morell
}

\begin{abstract}
Background-Pigeon breeder's disease is an extrinsic allergic alveolitis in the lungs of sensitised people, caused by hypersensitivity reactions to inhaled pigeon antigens. Antigens from different sources of the animal are used for diagnostic purposes, with serum being the most widely used. Bloom is rarely used; very little is known of its antigenicity and diagnostic performance, particularly when used with the enzyme linked immunosorbent assay (ELISA) method, which is the most popular test as it permits measurement of the antibody response.
\end{abstract}

Methods-To (a) standardise an ELISA for the measurement of specific IgG against pigeon serum and pigeon bloom extract; (b) to establish reference values for specific IgG in 73 non-exposed controls, (c) to show the presence of specific IgG against pigeon serum and bloom in serum samples of 17 patients with bird fancier's lung and 11 asymptomatic fanciers, and $(d)$ to study the similarity of the two antigen sources by cross reactivity experiments.

Results-Reference values of specific IgG were defined with the 97.5 percentile (367.9 $\mathrm{U} / \mathrm{ml}$ for pigeon serum and 953.7 $\mathrm{U} / \mathrm{ml}$ for pigeon bloom extract). Of symptomatic patients $100 \%$ had values higher than the cut off for both antigens. In asymptomatic fanciers values were higher than the cut off for pigeon serum in $45 \%$ and bloom extract in 54\%. Cross reactivity experiments showed that the two antigens differed in antigenic content although some components may be common to both.

Conclusion-The ELISA methods used proved to be useful tools for evaluating specific IgG antibody responses against both antigens. The diagnostic performance of both ELISA methods performed with these antigen sources was similar, showing very high sensitivity but moderate specificity. Although some antigenic similarity was found between pigeon serum and bloom extract, cross reactivity studies showed that various antigens seemed to be specific to the bloom extract. However, the antigens responsible for pigeon breeder's disease seem to be present in both antigenic sources.

(Occup Environ Med 2000;57:159-164)

Keywords: antibodies; pigeons; ELISA
Pigeon breeder's disease, first described by Reed et $a l^{1}$ in 1965, is an extrinsic allergic alveolitis caused by hypersensitivity reactions to inhaled pigeon antigens in the lungs of sensitised people. The presence of specific antibodies in symptomatic people and delay between exposure and onset of symptoms suggest a pathogenetic type III hypersensitivity. Also, the finding that granuloma had formed in lung biopsies and the activation of $\mathrm{T}$ lymphocytes in these patients may also indicate cell mediated type IV hypersensitivity. ${ }^{2-5}$ Diagnosis of these diseases is based on a characteristic clinical picture accompanied by: (a) presence of specific antibodies to the causal antigens, $(b)$ positive skin prick test, ${ }^{67}$ (c) resolution of symptoms after avoidance of contact with the pigeons, ${ }^{8}$ and if required, (d) positive specific inhalation challenge. On occasions, a positive transbronchial, or rarely, open lung biopsy is necessary to confirm the diagnosis.

Owing to its simplicity and ease of performance, the identification of precipitating antibodies by countercurrent immunoelectrophoresis remains the most widely used technique in diagnosis (serodiagnosis) of this disease. However, this method lacks analytical sensitivity and provides no quantitative information on antibody concentrations. Consequently, current clinical trends are to substitute the precipitin technique by enzymoimmunoassay methods which have shown high sensitivity and reliability, are measurable, and furthermore permit differentiation of the responsible immunoglobulin isotype..$^{9}$

Antibody activity against a range of pigeon antigens has been described. ${ }^{11-13}$ These antigens have been shown in pigeon serum, intestinal mucin, ${ }^{14}{ }^{15}$ and, particularly, in the bloom from pigeon feathers. ${ }^{2}$ Pigeon serum is the antigen source most often used to measure the specific antibodies in this type of extrinsic allergic alveolitis.

Owing to the difficulty in obtaining antigenic extracts from these materials, studies aimed at measuring specific antibodies to antigenic sources other than serum are scarce ${ }^{16}$; furthermore, results are not conclusive. ${ }^{16} 17$

Bloom is a fine dust consisting of flattened squamous keratinised epidermal cells of pigeons ${ }^{18}$ which is readily deposited on hands and clothing during handling of the birds. It has been suggested that bloom has strongly antigenic properties. ${ }^{19}$

The aim of this study was to standardise an enzyme linked immunosorbent assay (ELISA) for the measurement of specific IgG against 
Table 1 Background details of pigeon fanciers in study

\begin{tabular}{lll}
\hline & $\begin{array}{l}\text { Symptomatic } \\
\text { patients }\end{array}$ & $\begin{array}{l}\text { Asymptomatic } \\
\text { fanciers }\end{array}$ \\
\hline Subjects (n) & 17 & 11 \\
Age (mean, y) & 43 & 33 \\
Sex & $14 \mathrm{f} / 3 \mathrm{~m}$ & $11 \mathrm{~m}$ \\
Smoking history: & 0 & \\
$\quad$ Current smoker & 2 & 5 \\
Ex-smoker & 15 & 0 \\
$\quad$ Non-smoker & 6 \\
Exposure to pigeons (mean): & 24 & 87 \\
$\quad$ Pigeons kept (n) & 67 & 12 \\
Contact/week (h) & 147 & 216 \\
$\quad \begin{array}{l}\text { Duration pigeons kept } \\
\text { (months) }\end{array}$ & \\
Serum immunoglobulins (mean): & \\
IgG (mg/dl) & 1277 & 1102 \\
IgA (mg/dl) & 279 & 202 \\
IgM (mg/dl) & 130 & 138 \\
IgE (IU/ml) & 42 & 31 \\
\hline
\end{tabular}

two pigeon antigen sources (pigeon serum and pigeon bloom extract) to replace the precipitating antibody as the usual diagnostic method. We wanted to find whether differences exist between patients with pigeon breeder's disease and asymptomatic fanciers in the antigenic response to pigeon bloom and pigeon serum proteins, and to find whether antibodies to pigeon bloom extract would have greater diagnostic potential than antibodies to pigeon serum proteins. Thus, similarities and differences in antigenic composition were also studied.

\section{Materials and methods}

STUDY POPULATION

Seventeen patients with pigeon breeder's disease were studied ( 13 women, four men; mean age 35 years; range $22-58$ ). All the patients fulfilled diagnostic criteria for extrinsic allergic alveolitis: all have precipitated antibodies (by countercurrent immunoelectrophoresis) and had a positive inhalation test or a lung biopsy with changes typical of extrinsic allergic alveolitis. Eleven asymptomatic fanciers (all men; mean age 43 years; range 25-65) were also studied; of these, only four (39\%) have precipitated antibodies. Details of these two groups are given in table 1 .

Seventy three asymptomatic non-exposed people ( 54 women, 19 men; mean age 39 years; range 24-67) were studied as a control group.

The study was approved by the hospital ethics committee.

ANTIGENS

Pigeon serum and bloom extract were used as antigens. Blood was collected from a vein under the wing of three pigeons and centrifuged; the serum protein concentration was measured by bicinchoninic acid assay (Pierce Chemicals, Rockford, Ill). Protein concentration was $2.15 \mathrm{~g} / \mathrm{dl}$. Bloom was obtained by aspiration, collecting the feather dust of 20 pigeons from a filter fitted onto a mini-vacuum cleaner.

Antigenic extract from pigeon bloom was prepared by defatting the raw material with anhydrous ether at $37^{\circ} \mathrm{C}$ in a Soxhlet apparatus (Corning, Stone, Staffordshire, England) for 4 hours. ${ }^{20}$ Material was then dried and extracted $(1: 20 \mathrm{w} / \mathrm{v})$ in $0.2 \mathrm{~mol} / 1$ ammonium bicarbo- nate, $\mathrm{pH} 7.9$, overnight at $4^{\circ} \mathrm{C}$. The solution was centrifuged and the supernatant dialysed overnight at $4^{\circ} \mathrm{C}$ against deionised water in a 3.500 molecular weight cut off membrane (Spectra/Por; Spectrum Medical Industries, Los Angeles, CA, USA) until a clear extract was obtained. The material was lyophilised and the protein concentration measured by the bicinchoninic acid assay method. The bloom extract had a protein concentration of 0.22 $\mathrm{g} / \mathrm{dl}$.

ASSAYS FOR TOTAL IMMUNOGLOBULINS

Non-specific IgG, IgA, and $\operatorname{IgM}$ concentrations were measured by kinetic nephelometry (Array Protein System, Beckman-Instruments, Bre, CA, USA). Reference values established in our laboratory were: IgG 8.5-16 g/l; IgA 0.75$3.5 \mathrm{~g} / 1 ; \operatorname{IgM} 0.58-2.5 \mathrm{~g} / 1$. Concentrations of IgE were measured by the UniCAP 100 system (Pharmacia AB, Uppsala, Sweden). Reference values were $<100 \mathrm{IU} / \mathrm{ml}$.

SPECIFIC IgG TO PIGEON SERUM AND BLOOM Specific IgG was measured by an ELISA based on the method described by Metzger et $a l^{21}$ modified with pigeon serum or bloom extract as the antigen. Wells of high binding microtitre plates (Costar, Cambridge, MA, USA) were incubated with $2 \mu \mathrm{g}$ protein/well in $0.1 \mathrm{M}$ $\mathrm{Na}_{2} \mathrm{CO}_{3} / \mathrm{NaHCO}_{3}$ buffer, $\mathrm{pH} 9.6$, at $4^{\circ} \mathrm{C}$ overnight. The wells were then washed three times with washing buffer $(0.1 \mathrm{M}$ phosphate buffered saline, $\mathrm{pH} 7.5 / 0.005 \%$ Tween 20) and blocked with phosphate buffered saline $/ 1 \%$ bovine serum albumin for 1 hour at $37^{\circ} \mathrm{C}$. Washing the plates four times between steps, the specific IgG assays were performed in duplicate by incubating the serum samples at an appropriate dilution and the standard curve for 2 hours at $37^{\circ} \mathrm{C}$. A solution of horseradish peroxidase labelled antihuman IgG (clone MH16-1ME, $0.5 \mathrm{mg} / \mathrm{ml}$ ) diluted at 1:1000 was added and the plates incubated for 2 hours at $37^{\circ} \mathrm{C}$. The reaction was developed with 3,3',5,5'tetramethyl-benzidine (Sigma Chemicals), 3\% $\mathrm{H}_{2} \mathrm{O}_{2}$ for 20 minutes at room temperature in the dark and stopped with $2 \mathrm{M} \mathrm{H}_{2} \mathrm{SO}_{4}$, and the optical density at $450 \mathrm{~nm}$ was measured with a microplate reader (Titertek Multiskan Plus MKII).

Results were expressed as arbitrary units of ELISA using a reference pool serum with an assigned value of $5 \times 10^{4} \mathrm{U} / \mathrm{ml}$ for the two antigen sources. The pool was obtained with serum samples from precipitin positive symptomatic patients. Within run coefficients of variation for pigeon serum and bloom extract were 5.4\% and $7.8 \%$, respectively. Day to day coefficients of variation for the two antigen sources were $8.3 \%$ and $9.5 \%$, respectively.

To study the behaviour of serum samples compared with the reference pool, titrations were performed of four serum samples with optical density values at $450 \mathrm{~nm}$ between 1.3 and 0.5 for pigeon serum and 2.5 and 0.5 for bloom extract. The curves obtained from the serum samples and reference serum were plotted for linear regression analysis. ${ }^{22}$ 

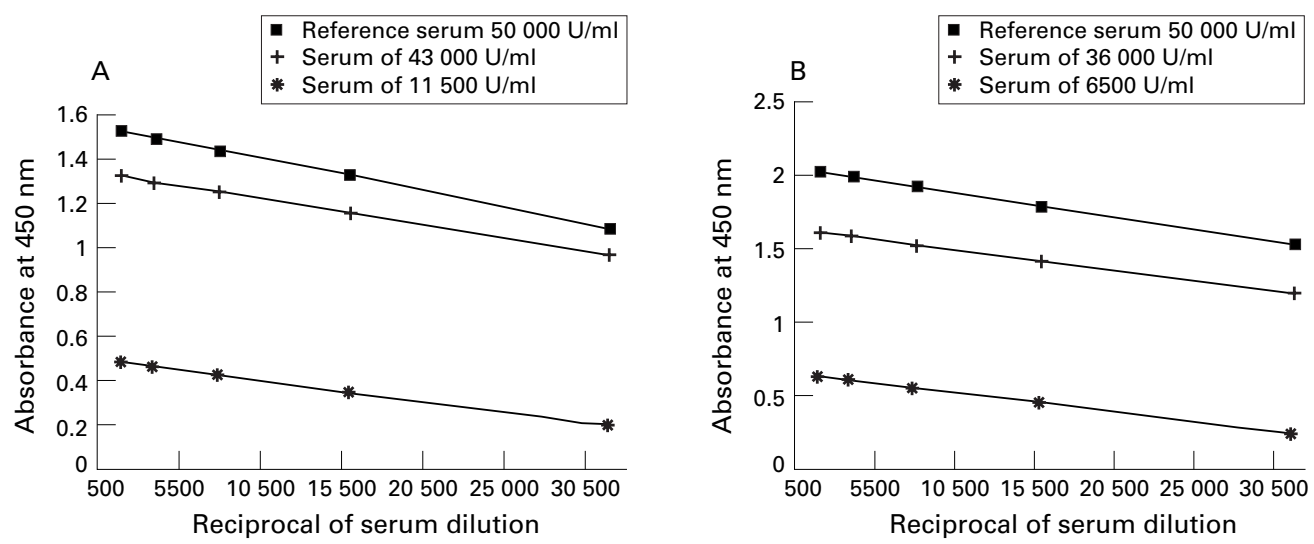

Figure 1 Regression lines for the reference serum and samples with different specific IgG antibody titres (A) to pigeon serum and (B) to pigeon bloom extract. No significant differences in the slopes of the lines were obtained by multiple regression analysis.

The minimum amount of specific IgG detectable with this assay was $0.4 \mathrm{U} / \mathrm{ml}$ for the two antigen sources. This value was obtained as the mean plus $3 \mathrm{SDs}$ of the calibrator 0 performed in 30 determinations.

\section{CROSS REACTIVITY STUDY BETWEEN BOTH ANTIGENS}

The method was the same as that used for specific IgG measurement, with the following modifications: wells of high binding microtitre plates (Costar, Cambridge, MA, USA) were coated with pigeon serum or pigeon bloom extract. After washes $(0.1 \mathrm{M}$ phosphate buffer/ $0.1 \%$ Tween 20 ), the plates were incubated with $50 \mu \mathrm{l} /$ well of an undiluted pool of serum from the allergic patients with a high concentration of specific IgG to both antigenic sources, and increasing concentrations (0-100 $\mu \mathrm{g}$ ) of pigeon serum or pigeon bloom as inhibitor antigens, for 2 hours at $37^{\circ} \mathrm{C}$. After three washes, horseradish peroxidase labelled antihuman IgG (clone MH16-1ME, $0.5 \mathrm{mg} / \mathrm{ml}$ ) diluted at 1:1000 was incubated for 2 hours at $37^{\circ} \mathrm{C}$. After washing, the reaction was developed with 3,3',5,5'-tetramethyl-benzidine (Sigma Chemicals), $3 \% \mathrm{H}_{2} \mathrm{O}_{2}$ for 20 minutes at room temperature in the dark. The reaction was stopped with $2 \mathrm{M} \mathrm{H}_{2} \mathrm{SO}_{4}$ and the optical density at $450 \mathrm{~nm}$ measured with a microplate reader (Titertek Multiskan Plus MKII).

The concentration of free antigen was plotted against percentage inhibition, and from this the concentration required to give $50 \%$ inhibition was calculated. Also, the inhibition lines had a measurable slope and comparison of the slopes of the extract was a measure of antigenic relatedness.

STATISTICAL ANALYSIS

The Kolmogorov-Smirnov test was used to check the fit of the data. Significant differences

Table 2 Specific IgG against pigeon serum and pigeon bloom extract in the non-exposed control group

\begin{tabular}{llllll}
\hline Extracts & $\begin{array}{l}\text { Mean } \\
\text { value }\end{array}$ & $95 \%$ CI & Median & Range & Cut offt \\
\hline Pigeon serum & 116 & 114 to 160 & 108 & $33-645$ & $367^{\star}$ \\
Bloom extract & 473 & 460 to 549 & 475 & $215-1098$ & 953 \\
\hline
\end{tabular}

${ }^{\star} \mathrm{p}<0.005 v$ pigeon bloom extract.

†97.5th percentile. between raw data and normal distribution were found. Therefore, non-parametric methods were used. Differences in mean values for each group were tested by the Mann-Whitney $U$ test, and correlation coefficients between specific IgG against pigeon serum and bloom extract values were performed by the Spearman rank test. Multiple regression analysis with the SPSS statistic program was used to compare the similarity of the slopes of the regression lines obtained (linearity and cross reactivity studies). A $p$ value $<0.05$ was considered to be significant.

\section{Results}

LINEARITY OF THE ELISA METHOD

Every single serum sample was tested at seven different dilutions to create a curve. The regression lines were created with five points. Figure 1 shows the regression lines generated for pigeon serum (A) and pigeon bloom extract (B). No significant differences in the slopes of the lines were obtained by multiple regression analysis ( $p=0.52$ and $p=0.44$, respectively). Thus it may be assumed that the behaviour of serum samples and the reference serum do not differ.

VALUES OF SPECIFIC IgG AGAINST PIGEON SERUM AND BLOOM EXTRACT IN THE CONTROL GROUP, IN PATIENTS WITH BIRD FANCIER'S LUNG, AND IN ASYMPTOMATIC FANCIERS

Concentrations of specific IgG against pigeon serum and bloom in the non-exposed control group are shown in table 2 . The reference values were defined as the $97.5 \%$ percentile.

Table 3 shows concentrations of specific IgG against pigeon serum and bloom in patients with bird fancier's lung and in asymptomatic fanciers. Results were considered positive if they exceeded the reference value. Values of specific IgG to pigeon serum and bloom in the asymptomatic fanciers were higher than the cut off in $45 \%$ and $54 \%$, respectively. All symptomatic patients $(100 \%)$ had values higher than the cut off.

The highest correlation was found between specific IgG to pigeon serum and bloom extract in the asymptomatic group $(r=0.84$, $\mathrm{p}<0.01)$. Other significant correlations were 
Table 3 Specific IgG against pigeon serum and pigeon bloom extract in patients with bird fancier's lung and asymptomatic fanciers

\begin{tabular}{llrrr}
\hline Extracts & Patients & Median & \multicolumn{1}{c}{ Range } & Positive (\%) \\
\hline Pigeon serum & Asymptomatic & 252 & $59-188145$ & 45 \\
& Symptomatic & 19996 & $4134-440970$ & 100 \\
Bloom extract & Asymptomatic & 979 & $505-253443$ & 54 \\
& Symptomatic & 14718 & $4478-63480$ & 100 \\
\hline
\end{tabular}

found in the control group and patients $(r=0.33, \mathrm{p}<0.01$ and $r=0.57, \mathrm{p}=0.02$, respectively).

COMPARISON OF SPECIFIC IgG AGAINST PIGEON SERUM AND BLOOM EXTRACT BETWEEN THE CONTROL GROUP, PATIENTS WITH BIRD FANCIER'S LUNG, AND ASYMPTOMATIC FANCIERS

The specific IgG concentration in the three groups studied is shown in figure 2. Significant differences were found between the nonexposed control group and the asymptomatic fanciers against pigeon serum and also against bloom extract $(p<0.01)$, and also between the non-exposed control group and symptomatic patients $(\mathrm{p}<0.01)$. No significant differences were found between asymptomatic and symptomatic patients to both antigenic sources.

CROSS REACTIVITY EXPERIMENTS

Results of cross reactivity experiments between pigeon serum and bloom are shown in figure 3. Slopes of the regression lines obtained in the

A

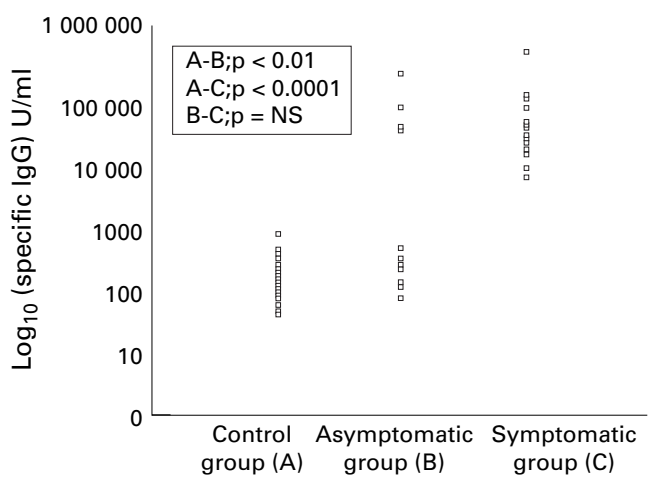

inhibition experiments showed no significant differences by multiple regression analysis when the coated antigen was pigeon serum $(p=0.06)$. Significant differences were found when the coated antigen was pigeon bloom $(\mathrm{p}=0.02)$. This did not seem to be due to cross reacting antibodies as the pigeon bloom concentration required to produce $50 \%$ inhibition when the coated antigen was pigeon serum was lower $(135 \mu \mathrm{g})$ than the pigeon serum concentration needed to produce $50 \%$ inhibition when the coated antigen was bloom $(1549 \mu \mathrm{g})$, suggesting that there is only minor cross reactivity between the two antigen sources.

Also, these results suggest that the relative potency of pigeon bloom was stronger than pigeon serum when the quantity of each extract required to produce $50 \%$ inhibition was compared.

\section{Discussion}

In this study the IgG response to both pigeon serum and pigeon bloom was quantitatively assessed by ELISA to measure whether responses differ between symptomatic and asymptomatic people. The results show that the ELISA method described in this study is a useful tool for evaluating the specific IgG antibodies, and also that although various antigens seemed to be specific for bloom extract, an

Figure 2 Specific IgG concentration to pigeon serum (1) and pigeon bloom extract (2) (A) in the control group, (B) asymptomatic fancier's, and (C) symptomatic patients. No significant differences were found between asymptomatic and symptomatic patients to both antigenic sources.
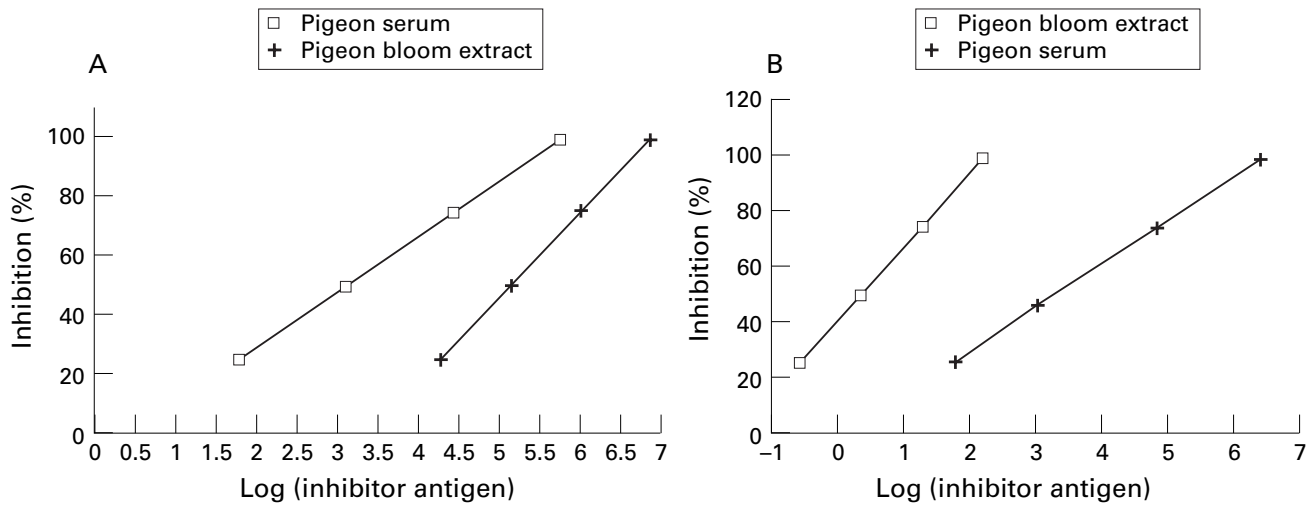

Figure 3 Cross reactivity experiments for specific IgG antibodies, using as solid phase: (A) pigeon serum and (B) pigeon bloom extract. The pigeon bloom concentration that produced $50 \%$ inhibition when the coated antigen was pigeon serum was lower $(135 \mu \mathrm{g})$ than the pigeon serum concentration that produced $50 \%$ inhibition when the coated antigen was bloom extract $(1549 \mu \mathrm{g})$. 
antigenic similarity was found between these two antigenic sources.

Specific IgG measurement to avian antigens by ELISA method in the diagnosis of pigeon breeder's disease constitutes an advance compared with classic precipitating antibody measurement as it has better analytical sensitivity $(10-1000 \mathrm{ng} / \mathrm{ml})$ and specificity. ${ }^{9}$ Also, the ELISA is more useful for the detection of antibodies against pigeon antigens in fluids with a low protein content-such as bronchoalveolar lavage - as reported by Sandoval et al. ${ }^{16}$ These authors, in a comparative study for the detection of specific antibodies by countercurrent immunoelectrophoresis and ELISA in the bronchoalveolar lavage of patients with extrinsic allergic alveolitis, found that $12 \%$ and $100 \%$ were positive, respectively. Simpson et al, ${ }^{23}$ in a study of specific antibodies against pigeon serum by double immunodiffusion and ELISA in serum and bronchoalveolar lavage of patients with pigeon breeder's disease, also showed the ELISA method to have higher sensitivity $\left(10^{3}\right.$ times) than the double immunodiffusion method.

In the absence of standards, which are currently unavailable, for measuring specific IgG against avian antigens, the results of our study were expressed in arbitrary $\mathrm{U} / \mathrm{ml}$ referred to our own reference serum with an assigned value of $5 \times 10^{4} \mathrm{U} / \mathrm{ml}$ for the two antigen sources. This reference pool was obtained with serum samples from symptomatic patients with positive antibody results by countercurrent immunoelectrophoresis. The results of multiple regression analysis of the linearity study showed the validity of this standard, as the behaviour of serum samples in a large interval of dilutions and the reference serum do not differ (fig 1).

The ELISA method used in the present study showed for pigeon serum and pigeon bloom that $100 \%$ of symptomatic fanciers had values higher than the cut off established in this study, whereas in asymptomatic fanciers the percentages were $45 \%$ and $54 \%$, respectively. These percentages are similar to those reported by Andersen et $a l^{4}$ with a countercurrent immunoelectrophoresis method who found precipitating antibodies in $100 \%$ of symptomatic patients and $60 \%$ of asymptomatic fanciers. Beer et $a l^{25}$ with western blot, an expensive and time consuming procedure, found that all the symptomatic patients as well as $57 \%$ of the asymptomatic fanciers were positive to pigeon serum.

Simpson et $l^{23}$ with an ELISA method and a pigeon faecal extract as antigen, found a positive reaction in $100 \%$ of $1: 100$ diluted serum samples of patients with the disease, whereas a positive immunodiffusion reaction was detected with undiluted serum samples in only $80 \%$ of these patients. At present, the use of faecal extract as an antigen source has been ruled out owing to the possible positive precipitins when the patient's serum reacts to the teichoic acid of the Staphylococcus capsule, which is a frequent contaminant of bird droppings. ${ }^{26}$

To our knowledge, no studies have been published which focus on measuring specific
IgG antibodies to pigeon bloom extract by an ELISA method. Thus, we have been unable to compare our results, as authors who study this antigenic source use other techniques. ${ }^{2425}$

The results of the present study show that both patients who develop the disease and asymptomatic exposed people synthesise high concentrations of class IgG antibodies against both pigeon serum and bloom extract. With the ELISA method standardised in this study, values of specific IgG to pigeon bloom extract are triple those to pigeon serum in the control group, and the percentage of asymptomatic breeders with antibodies was also higher for the pigeon bloom extract. These results are similar to those reported by Banham et al, ${ }^{19}$ which would suggest that pigeon bloom is a more potent antigen source than pigeon serum.

Furthermore, the cross reactivity studies conducted in our work with inhibition experiments between pigeon serum and bloom extract show that a greater concentration of pigeon serum is required to inhibit pigeon bloom than the other way round. This could indicate that bloom is a more potent antigenic source than pigeon serum and that the extracts differ in antigen content. Longbottom et al, ${ }^{18}$ in a study to investigate the antigenicity of a pigeon bloom extract by crossed immunoelectrophoresis, identified 29 antigenic components in the bloom and only 10 in pigeon serum. Although some antigenic similarity was found between pigeon bloom and serum, various antigens seemed to be specific. These results concur with those of our study and would corroborate our previous comments. More recently, Baldwin et $a l^{15}$ studied the response of IgG and specific IgG subclasses to pigeon serum and intestinal mucin in a group of symptomatic people and another group of asymptomatic exposed subjects and found higher specific IgG values against intestinal mucin than against pigeon serum in both groups. However, in patients with extrinsic allergic alveolitis, contrary to Baldwin et $a l^{3}$ values of specific IgG to both antigenic sources are similar; this induces us to think that the antigen which causes the symptoms is present in both pigeon serum and bloom extract.

A notable point of the work of Baldwin et al is that they found no significant differences in the composition of specific IgG subclasses against pigeon serum between symptomatic and asymptomatic people, but differences were found in the composition of subclasses against mucin, with significantly higher IgG1 titres in the patient group. These results concur with those found by our group in patients with extrinsic allergic alveolitis caused by inhalation of mollusc shell dust ${ }^{27}$ where the specific IgG1 against mollusc shell dust extract was the more abundant subclass, suggesting that it could be the principal antibody involved in the pathogenesis of this disease. These results support the importance of the study of specific IgG subclasses against different avian antigen sources, as the results of specific IgG do not seem to show any difference in response between the group of patients with symptoms and asymptomatic subjects. 
In conclusion, this study shows that: (a) specific IgG measurement by an ELISA method is more sensitive for detecting exposure to antigens than the precipitating antibodies study, $(b)$ the ELISA described proved to be a useful tool for evaluating specific IgG responses against pigeon serum and pigeon bloom, and (c) although bloom has some antigens different from pigeon serum, in patients with extrinsic allergic alveolitis, the results obtained in this study show that the antigens responsible for the disease are found in both pigeon serum and bloom extract.

Further studies should be conducted with measurement of specific IgG subclasses against both antigen sources, as their profiles may provide greater understanding of the pathogenetic mechanisms and of how to explain why only some exposed people develop the disease. In this line, studies are currently underway in our laboratory in an attempt to find by sodium dodecylsulphate-polyacrylamide gel electrophoresis (SDS-PAGE) and western blot the identification and purification of some antigenic proteins of these avian antigenic sources recognised by serum samples of affected people.

This research has been supported in part by a grant from Fondo de Investigaciones Sanitarias (FIS 93/0448). We thank Cristina O'Hara for help with the english translation of the manuscript.

1 Reed CE, Sosman A, Barbee RA. Pigeon breeder's lung. FAMA 1965;193:261-4

2 Newman-Taylor AJ. Extrinsic allergic alveolitis. In: Brewis R, Corrin B, Geddes DM, Gibson GJ, eds Respiratory medicine, 2nd ed. London: WB Saunders, 1995:1394-402.

3 Baldwin CI, Todd A, Bourke S, et al. Pigeon fancier's lung: effects of smoking on serum and salivary antibody responses to pigeon antigens. Clin Exp Immunol 1998;113: 166-72.

4 Yoshizawa Y, Miyashita Y, Inoue T, et al. Sequential evaluation of clinical and immunological findings in hypersensitivity pneumonitis: serial subclass distribution of antibodtivity pneumonitis: serial subclass distribution of
ies. Clin Immunol Immunopathol 1994;73:330-7.

5 Morell F, Orriols R, Antó JM, et al. El test de inhibición de Morell F, Orriols R, Anto JM, et al. El test de inhibición de
la migración de los leucocitos en el pulmón del cuidador de aves. Allergol Immunopathol (Madr) 1980;(suppl VII): aves.

6 Morell F, Orriols R, Molina C. Usefulness of skin test in farmer's lung. Chest 1985;87:202-5.

7 Morell F, Curull V, Orriols R, et al. Skin test in bird breeder's disease. Thorax 1986;41:538-41.

8 Richerson HB, Bernstein IL, Fink JN, et al. Guidelines for the clinical evaluation of hypersensitivity pneumonitis.
Report of the Subcommittee on Hypersensitivity Pneumonitis. F Allergy Clin Immunol 1989;84:839-44.

9 Kurup VP, Fink JN. Immunological tests for evaluation of hypersensitivity pneumonitis and allergic bronchopulmonary aspergillosis. In: Rose NR, Folds JD, Nakamura RM, eds. Manual of clinical laboratory immunology, 5th ed. American Society for Microbiology 1997;908-15.

10 Krasnick J, Meuwissen HJ, Nakao MA, et al. Hypersensitivity pneumonitis: problems in diagnosis. $\mathcal{F}$ Allergy Clin Immunol 1996;97:1027-30.

11 Edwards JH, Barboriak JJ, Fink JN. Antigens in pigeon breeder's disease. Immunology 1970;43:327.

12 Berrens L, Maesen FP. An immunochemical study of pigeon breeder's disease, II. The specific antigens. Int Arch Allergy Clin Immunol 1972;43:27.

13 Fredricks WW, Tebo TH. An antigen of pigeon breeder's disease. Fed Proc 1975;34:984.

14 Todd A, Coan RM, Allen A. Pigeon breeder's lung: pigeon ntestinal mucin, an antigen distinct from pigeon IgA. Clin Exp Immunol 1991;85:453-8.

15 Baldwin CI, Todd A, Bourke SJ, et al. IgG subclass responses to pigeon intestinal mucin are related to development of pigeon fancier's lung. Clin Exp Allergy 1998;28:349-57.

16 Sandoval J, Banales JL, Cortes JJ, et al. Detection of antibodies against avian antigens in bronchoalveolar lavage from patients with pigeon breeder's disease: usefulness of enzyme-linked immunosorbent assay and enzyme

Calvanico NJ. A component of pigeon dropping extract that reacts specifically with sera of individuals with pigeon breeder's disease. F Allergy Clin Immunol 1986;77:79-86.

18 Longbottom JL. Pigeon breeder's disease: quantitative mmunoelectrophoretic studies of pigeon bloom antigen. Clin Exp Allergy 1989;19:619-24.

19 Banham SW, McKenizie H, McSharry C, et al. Antibody against a pigeon bloom extract: a further antigen in pigeon fancier's lung. Clin Allergy 1982;12:173-8.

20 Rodrigo MJ, Morell F, Helm RM, et al. Identification and partial characterization of the soybean-dust allergens involved in the Barcelona asthma epidemic. $\mathcal{F}$ Allergy Clin Immunol 1990;85:778-84.

21 Metzger WJ, Butler JE, Swanson P, et al. Amplification of the enzyme-linked immunosorbent assay for measuring
allergen-specific IgE and IgG antibody. Clin Allergy 1981:11:523-31.

22 Rodrigo MJ, Miravitlles M, Cruz MJ, et al. Characterization of specific IgG and its subclasses (IgG1 and IgG2) against the 23 -valent pneumococcal vaccine in a healthy adult population: proposal for response criteria. Clin Diag Lab Immunol 1997;4:168-72.

23 Simpson C, Shirodaria PV, Evans JP, et al. Comparison of immunodiffusion and enzyme-linked immunosorbent assay in the detection of abnormal antibodies in pigeon breeder's disease. F Clin Pathol 1992;45:490-3.

24 Andersen P, Christensen KM, Jensen BE. Antibodies to pigeon antigens in pigeon breeders. Eur $\mathcal{F}$ Respir Dis 1982; 63:113-21.

25 De Beer PM, Bonic PJ, Joubert JR. Identification of a "disease-associated" antigen in pigeon breeder's disease by western-blotting. International Archives of Allergy and Applied Immunology 1990;91:343-7.

26 Faux JA, Holford-Strevens V, Vells ID. False positive precipitation reaction to extracts of organic dust due to teihoic acid from S aureus. Clin Exp Immunol 1970;7:897902.

27 Codina R, Rodrigo MJ, Orriols R, et al. Extrinsic allergic alveolitis caused by inhalation of mollusc shell dust. Allergologie 1989;30:03.44A. 